\title{
In vivo and haematological study of some selected vegetable condiments
}

\begin{abstract}
Basil Leaf, Efirin, daidoya, nchanwu or scent leaf, whose botanical name is Ocimum gratissimum, is a tropical plant species that belongs to the family of Labiatae. Bitter leaf as the name implies, is a plant that is often known for its bitter taste, but underneath that bitterness, both plants classify as vegetable condiment because of the attribute such as its flavour, taste and domineering to the sauce. The objective of this project is to formulate dietary, conduct in vivo and haematological study of vegetable condiments, basil leaf (ocimum gratissimum) and bitter leaf (vernonia amygdalina) Nigeria. The vegetable condiments dietary formulated consisted of Basal Dietary (BD), Control Dietary (CD), Basil 10\% Platelet 10\% Basal 80\% Dietary (BPB), Platelet 10\% Bitter 10\% Basal 80\% Dietary (PBB), Bitter 10\%, Basil 10\% Basal $80 \%$ Dietary (BBB). Fifty (50) albino rats were randomly selected weighed and grouped into five groups of ten each. They were assigned to formulated dietary. The result showed that the growth rate, non protein diet (BD), declined from 71.50-70.88, protein dietary increased for Control (CD) 112.84-71.74, basil (BPB), 116.02-71.70, bitter leave (PBB), 83.04-71.70, basil bitter leave (BBB) 83.50-71.20. Bioassay analysis revealed that NPR, PRE and NPU of experimental dietary were favorably comparable to the control dietary. It was concluded that basil dietary compared with bitter leaf had the best growth response, both have medicinal value, home available, has health benefits. Nitrogen retention is present in various tissues of the internal organ which is adequate for bodybuilding. Nutrient compositions in the dietary samples meet daily nutrient requirement intake and amino acid profile that is adequate to complement human diet. Protein quality of both basil leaf (ocimum gratissimum) and bitter leaf (vernonia amygdalina) are viable to promote human growth. Basil leaf (ocimum gratissimum) and bitter leaf (vernonia amygdalina) has confirmed to be source of Vitamin-A, K and mineral to support and improve human health. In summary the haematology study has confirmed that consuming dietary contain Vegetable condiments such as bitter leaf (vernonia amygdalina), basil leaf (ocimum gratissimum) will enable children pregnant woman and elderly to be free of Infection such as leukemia, anemia, bleeding, malnutrition, kidney disease, polycythemia, and blood related disease.
\end{abstract}

Keywords: vegetable, condiment, in vivo study, bitterness, basil leave
Volume 6 Issue 3 - 2018

\author{
Samson Ishola Ibironke,' Adefisola Bola \\ Adepeju, ${ }^{2}$ Olatunde Otutu, ${ }^{2}$ Damilola Sayo \\ Oyedele, ${ }^{2}$ Yetunde Oyebola Esan, ${ }^{2}$ Isaac \\ Owotomo ${ }^{3}$ \\ 'Department of Food Science and Technology, Obafemi \\ Awolowo University, Nigeria \\ ${ }^{2}$ Department of Food Science and Technology, Joseph Ayo \\ Babalola University, Nigeria \\ ${ }^{3}$ Department of Haematology and Immunology, Obafemi \\ Awolowo University, Nigeria
}

Correspondence: Samson Ishola Ibironke, Department of Food Science and Technology, Faculty of Technology, Obafemi Awolowo University, Ile-Ife, Osun State, Nigeria,

Email isolaibironke@yahoo.com

Received: April 30, 2018 | Published: June 26, 2018
Abbreviations: $\mathrm{BD}$, basal dietary; $\mathrm{CD}$, control dietary; $\mathrm{BPB}$, Basil 10\% Platelet 10\% Basal 80\% Dietary; PBB, Platelet 10\% Bitter 10\% Basal 80\% Dietary; BBB, Bitter 10\% Basil 10\% Basal $80 \%$ Dietary

\section{Introduction}

Basil Leaf, Efirin, daidoya, nchanwu or scent leaf, whose botanical name is Ocimum gratissimum, is a tropical plant species that belongs to the family of Labiatae. A vegetable condiment give our diet better taste and improve our appetite to taken food. ${ }^{1-3}$ Bitter-leaf is mostly available around our house Basil Leaf and bitter leave has confirmed to be source of Vitamin-A, K and mineral to support and improve human health. Basil has Vitamin K which is essential for the production of clotting factors in the blood and plays a vital role in the bone strengthening and mineralization. Basil herb contains a good amount of minerals micro and macro mineral element for human development. ${ }^{4-6}$ Basil contain oil called Eugenol, it is an important essential oil that acts against the enzyme (cyclooxygenase) oil obtained from basil herb has been confirmed to have anti-infective to many pathogenic bacteria inhibitor. ${ }^{4-7}$. Bitter-leaf are noted for its major roles in maintaining the livers, kidney effective performance, and pancreas in the body for optimum health, help to release bile acid every time people eat fatty foods. Other major function of bitter liver is the production of glycogen. Bitter-leaf has reported help useful in taking care of the kidney and the liver and production of animal starch (glycogen). Some researcher has established that taken bitter leaf can lower and neutralized high blood sugar level in diabetic patient. ${ }^{1-3}$ Bitter leaf can repair damage pancreas which is responsible for the production of insulin for boost of glucose that supply to the body. ${ }^{1-3}$

\section{Material and methods}

Vegetable condiments, bitter leaf (vernonia amygdalina), basil leaf (ocimum gratissimum) and maize were bought from vegetable local supermarket at outskirt of Ile-Ife, Nigeria. It was sorted, washed reduced to sizes with knife and solar dried for 10 hours and pulverized into fine powder and made to pass metal mesh of size $0.50 \mathrm{~mm}$.

\section{Automated blood count}

\section{Procedures}

Blood Counts were determination such as WBC, RBC, HCT PLT and PCT was performed according to Ibironke et al. ${ }^{8}$

\section{Animal grouping experimentation}

\section{Experimental animal procedure}

White Wister, fifty white (50) albino rats of both sexes were purchased from the Faculty of Health science, Obafemi Awolowo University, Ile-Ife, Osun State, Nigeria. The weights of albino rats 
and ages taken and were ranged from $50-70 \mathrm{~g}$, also were noted to be between three to six weeks old, respectively. All the experiment animals were weighed on the scale carefully, selected randomly and divided into five experimental groups of ten per divisional group and was accommodated in a metabolic cage mesh. The experimental animal were familiarized to new environment and fed ad libitum with feed meant for animal. Each sectional group of animal was placed on the experimental dietary for over a period of 28days. Water and food were giving adequately ad libitum to five groups of ten animals each as allotted. Amount of food taken per day were recorded. The experiment animals were weighed in every three days for 28days and graphically represented. The faeces and urine of the experimental animals in the different groups was collected separately, urine was stored inside a bottle containing $6 \mathrm{~N}$ HCL to preserve it prior analysis, and the faeces was dried in an oven at $60^{\circ} \mathrm{C}$ for 12 hours, cooled, weighed and stored inside sealed polythene, per group. At the end of the 28days, the animals was weighed, anaesthetized and sacrificed. Tissue samples from liver, kidney and plantaris muscles were removed, Nitrogen in the faeces and urine was determined by the micro Kjeldahl method. ${ }^{9}$ The experimental organs were collected from the animal were immediately fixed in $10 \%$ formyl saline for further analysis such as Nitrogen retention. ${ }^{8,10}$

\section{Bioassay Calculations}

$$
\begin{aligned}
& \text { Protein efficiency ratio }(\text { PER })=\frac{\text { Weight gain of test animal }(\mathrm{g})}{\text { Protein consumed by the test animal }(\mathrm{g})} \\
& \text { Protein efficiency ratio }(\text { PER })=\frac{\text { Weight gain of test animal }(\mathrm{g})}{\text { Protein consumed by the test animal }(\mathrm{g})}
\end{aligned}
$$$$
\text { Net protein retention }(\mathrm{NPR})=\frac{\text { Weight gain of test animal }(\mathrm{g})+\text { Average Weight Loss of Animal }}{\text { Protein consumed by the test animal }(\mathrm{g})}
$$

$$
\begin{aligned}
\text { Protein retention efficiency }(\text { PRE }) & =\text { NPRX16 } \\
\text { Feed Conversion ratio was determined by } & =\frac{\text { Feed Consumed }(\mathrm{g})}{\text { Gain in body weight }(\mathrm{g})}
\end{aligned}
$$

\section{Ethical consideration}

White Wister, fifty albino rats were approved by the Animal Ethical Welfare Review Committee of the

\section{Obafemi Awolowo University, Osun State, Ile-Ife, Nigeria.}

Figure $1 \& 2$ shows the portrait of the scent leaf (Ocimum gratissimum) and bitter leaf (Vernonia Amygdalina) in the home garden.

\section{Chemical analysis}

Protein was determined by using microkjedal equipment and followed stages by digestion, distillation, and titration (nitrogenx6.25). Moisture was done using gallekamp oven 4 , crude fat was determined with soxhlet apparatus, carbohydrate was determined by different, and vitamin of the dietary samples were determined according to $\mathrm{AOAC}^{9}$ methodology.

\section{Energy value}

Caloric value was calculated $(\mathrm{kJ} / 100 \mathrm{~g})$ using the equation:

Energy value $=(37 \times$ fat $)+(17 \times$ carbohydrate $)+(17 \times$ protein $)$

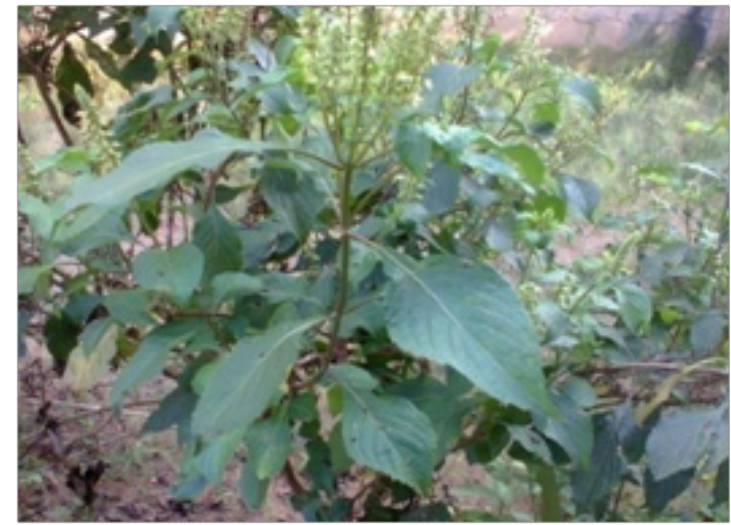

Figure I Ocimum gratissimum.

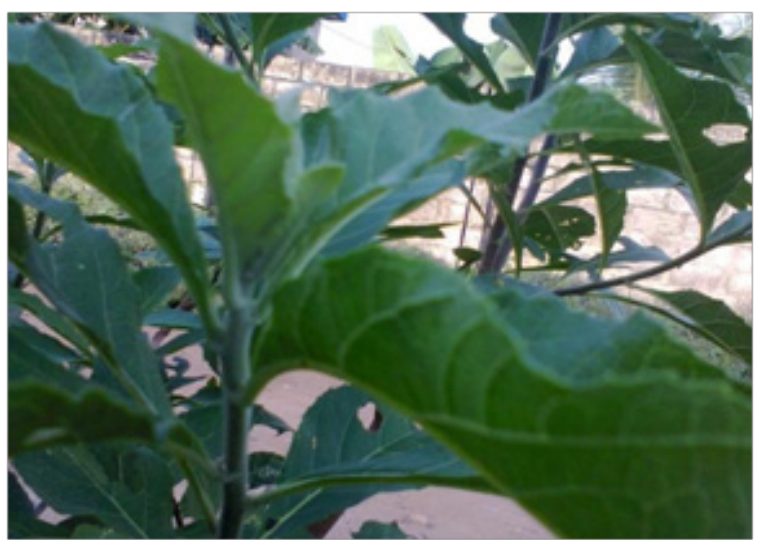

Figure 2 Vernonia Amygdalina.

\section{Result and discussion}

White Blood Cells including LYM\% were found rated high, It has ranged from 73.9-89.2 and above limit of 2.5-10.5 while values for $\mathrm{WBC} 10^{-3 / \mathrm{UL}}$, GRAN\% ranged from $4.3-15.6$ and has moderate for $\mathrm{MON} \%$ of ranged from $6.6-12.2$ and $\mathrm{MON} \#^{-3} \cdot{ }^{11-14}$ Red Blood Cells were found to be high in RBCs, $\mathrm{HGBg} / \mathrm{dl}$ was found moderate with ranged from 3.9-6.76, while HCT\% ranged from 29-39. ${ }^{15,16}$ Hemoglobin\% ranged from $11.7-13.6$ ( $\mathrm{Hb}$ or $\mathrm{Hgb}) .{ }^{11-14}$ (MCHC) were found to be high, ranged from 32-41.9 and it is above the limit of $32-36$. Some of the symptoms reported for low range are frequently tiredness and have little or no energy. This is because there is not enough hemoglobin to carry oxygen to the stationary tissues; thus, there is not enough oxygen available to convert nutrients into energy. The RBC count, hematocrit level, MCV, $\mathrm{MCH}$ and $\mathrm{MCHC}$ might also be low in patients with anemia. Low RBC counts, hemoglobin and hematocrit levels can be caused by other things too, such as a lot of bleeding or malnutrition (not enough nutrients in the food eaten. ${ }^{11-14}$ RDW-SDfL, PDW\% were found with low, platelets which helping to clot blood PCT\% PLT10 $0^{-3 / \mathrm{UL}}$ were found to be high ranged from 262-662 above the limit of 90-4000, MPVfL P. LCR\% were found to be moderate ${ }^{11-14}$ haemochromatosis and thalassemia (Figure 3) (Table 1). ${ }^{6,11-14,17-19}$

Table 2 reported the Chemical composition of basil and bitter leave Protein\% ranged from 14-42.88, Moisture\% ranged from 2.30-7.50, Fat $\%$ content ranged from $2.30-7$, Ash\% ranged from 4.22-4.30, Crude \% Fiber ranged from 3.80-6.50, Ash\% ranged from 4.22 4.30, $\mathrm{CHO} \%$ ranged from 40.36-66 and Dry\% Matter 97.50-97.80 
respectively. Protein content in bitter leave is about triple higher than that of basil leave both have moisture of less than $5 \%$ which indicates that they are less liable to micro-organism growth. The fat content is very low being obtained leaf extract. Mineral ash is quite adequate to supply mineral to the diet for body upkeep. They both have higher carbohydrate that required for source of energy. ${ }^{8,20-31}$

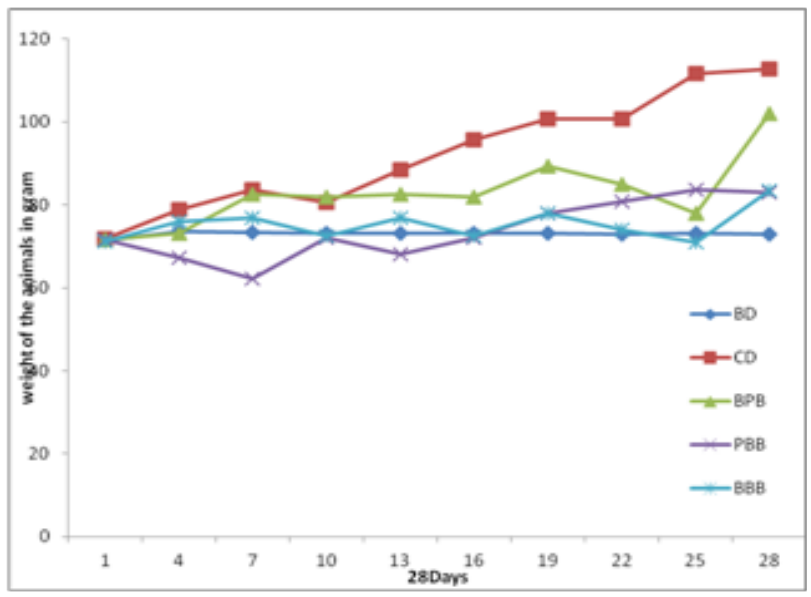

Figure 3 Animal grouping experimentation.

Abbreviations: $\mathrm{BD}$, basal dietary; $\mathrm{CD}$, control dietary; BPB, Basil $10 \%$ platelet $10 \%$ basal $80 \%$ dietary; PBB, Platelet 10\%bitter 10\% basal $80 \%$ dietary; BBB, bitter I0\%basil 10\% basal80\% dietary.

Table I Haematological Study of some Vegetable Condiments
Table 3 reflects the various tissues of the internal organ of the experimental animal, the Liver(g) ranged from 3.80-4.40, and Heart(g) ranged from $0.37-0.46 \mathrm{Kidney}$ right $(\mathrm{g})$ ranged from $0.36-0.48 \mathrm{Kidney}$ left $(\mathrm{g})$ ranged from $0.37-0.54$ respectively. It is noteworthy dietary the experiment animal had two kidney but left kidney were found higher in weight. Also, basil fortified diet were similar to control diet while basal diet were found similar in diet fortified with bitter leave, bitter taste may be due to concentrate of andrographolide content. ${ }^{2,6,32}$

Table 4 showcases the nitrogen retention in various tissues of the internal organ Kidney $\mathrm{mg} / \mathrm{g}$ ranged from 20.20-70.64, Liver $\mathrm{mg} / \mathrm{g}$ 20.05-70.08 Muscle $\mathrm{mg} / \mathrm{g}$ ranged from 10.30-70-78 Fecal $\mathrm{mg} / \mathrm{g}$ ranged from $10.30-0.86-$ Urine $\mathrm{mg} / \mathrm{g}$ ranged from $0.14-0.35$. The nitrogen retention of basal diet was very low compared to other experimental animal. ${ }^{33}$ The basil fortified dietary had the highest retention of nitrogen followed by control dietary. ${ }^{2,6,34-42}$

Table 5 reflects the Bioassay of the experimental animal Bioassay $\mathrm{BV} \%$ ranged from 59.60-72.06, NPU\% 1.33-4, 43, PER 1.10-4.40, FER 3, 78-6.85, NPR 1.07-4.37, PRE and 20, 16-69.92. The highest $\mathrm{BV} \%, \mathrm{NPU} \%$, PER, FER, NPR and PRE were found in basil fortified diet (BPB) when compared with control diet (CD). The basal diet (BD) had no biological value. The bitter leaf fortified diet (PBB) was also found to be less in biological value than mixture of bitter and basil leave diet. This may be responsible by andrographolide content responsible for bitterness in the leave as shown in figure one. ${ }^{2,6}$

\begin{tabular}{|c|c|c|c|c|c|c|c|}
\hline Parameter & BD & $C D$ & BPB & PBB & BBB & Limits & Alerts \\
\hline WBCI0-3/UL & 6.3 & 6.6 & 2.0 & 1.5 & 4.4 & $2.5-10.5$ & L \\
\hline LYM\% & 73.9 & 89.2 & 81.9 & 77.3 & 76.8 & $20-40$ & $\mathrm{H}$ \\
\hline MON\% & 6.8 & 6.6 & 7.5 & 7.1 & 12.2 & I5-Jan & $M$ \\
\hline GRAN\% & 14.1 & 4.3 & 10.6 & 15.6 & 11 & $50-70$ & L \\
\hline LYM\#"-3/UL & 8.6 & 6.6 & 1.6 & 1.2 & 3.4 & $0.6-4.1$ & M \\
\hline MON\#"-UL & I.4 & 0.4 & 0.2 & 0.1 & 0.5 & $0.1-1.8$ & L \\
\hline GRAN\#"3/UL & 1.6 & 0.3 & 0.2 & 0.2 & 0.5 & $2.0-7.8$ & L \\
\hline $\mathrm{RBC}^{-6 / \mathrm{UL}}$ & 6.76 & 6.62 & 6.39 & 6.68 & 6.47 & $3.50-6.50$ & $\mathrm{H}$ \\
\hline $\mathrm{HGBg} / \mathrm{dl}$ & 12 & 12.7 & 13.6 & 11.7 & 13.6 & 16-Nov & $M$ \\
\hline НСТ\% & 34.2 & 39.1 & 33.1 & 29 & 34.4 & $36-48$ & L \\
\hline MCVfL & 60.6 & 69.1 & 51.9 & 51.1 & 50.2 & $80-99$ & L \\
\hline $\mathrm{MCHpg}$ & 17.7 & 19.1 & 21.2 & 20.5 & 21 & $26-32$ & L \\
\hline $\mathrm{MCHCg/dl}$ & 32 & 32.4 & 41 & 40.3 & 41.9 & $32-36$ & $\mathrm{H}$ \\
\hline RDW-SDfL & 24.1 & 35.3 & 26 & 26 & 24.1 & $37-54$ & L \\
\hline RDW-CV\% & 13.6 & 17.4 & 13.7 & 13.9 & 13.1 & II.5-14.5 & $M$ \\
\hline PLTI0-3/UL & 440 & 503 & 428 & 264 & 622 & $90-400$ & $\mathrm{H}$ \\
\hline MPVfL & 6 & 6.7 & 6.9 & 9.4 & 6.9 & 7.4-10.4 & L \\
\hline PDW\% & 7 & 7.9 & 7.9 & 9.7 & 7.9 & $17-O c t$ & L \\
\hline РСТ\% & 0.47 & 0.33 & 0.29 & 0.24 & 0.42 & $0.10-0.28$ & $\mathrm{H}$ \\
\hline P.LCR\% & 13.3 & 18.3 & 18.5 & 18.5 & 18.4 & $13-43$ & $M$ \\
\hline
\end{tabular}


Table 2 Chemical composition of basil and bitter leave

\begin{tabular}{llllllcc}
\hline Sample code & Protein\% & Moisture\% & Fat\% & Ash\% & Crude fiber\% & CHO\% & Dry matter\% \\
\hline & $42.64 \pm 04$ & $2.30 \pm 02$ & $6.50 \pm 03$ & $4.30 \pm 01$ & $3.80 \pm 03$ & $40.46 \pm 04$ & $97.70 \pm 04$ \\
Bitter leave & $42.89 \pm 00$ & $2.40 \pm 02$ & $6.00 \pm 02$ & $4.22 \pm 00$ & $3.86 \pm 02$ & $40.61 \pm 03$ & $97.60 \pm 02$ \\
& $42.04 \pm 02$ & $2.50 \pm 03$ & $7.00 \pm 01$ & $4.26 \pm 04$ & $3.84 \pm 01$ & $40.36 \pm 02$ & $97.50 \pm 03$ \\
& $14.88 \pm 01$ & $2.50 \pm 02$ & $2.20 \pm 03$ & $4.24 \pm 02$ & $5.36 \pm 04$ & $66.88 \pm 03$ & $97.80 \pm 01$ \\
Scent Leaf & $15.32 \pm 02$ & $2.50 \pm 03$ & $2.25 \pm 02$ & $4.22 \pm 03$ & $6.50 \pm 02$ & $66.21 \pm 04$ & $97.75 \pm 02$ \\
& $14.00 \pm 02$ & $2.50 \pm 01$ & $2.30 \pm 04$ & $4.25 \pm 04$ & $6.00 \pm 03$ & $65.95 \pm 04$ & $97.70 \pm 03$
\end{tabular}

Mean $\pm S D$ values of five determinations $(P<0.05)$

Table 3 Various tissues of the internal organ of the experimental animals

\begin{tabular}{lllll}
\hline Dietary & Liver(g) & Heart(g) & Kidney right(g) & Kidney left(g) \\
\hline BD & $3.80 \pm 01$ & $0.37 \pm 02$ & $0.38 \pm 04$ & $0.37 \pm 00$ \\
CD & $4.36 \pm 02$ & $0.46 \pm 03$ & $0.48 \pm 03$ & $0.54 \pm 02$ \\
BPD & $4.38 \pm 04$ & $0.43 \pm 04$ & $0.48 \pm 04$ & $0.52 \pm 03$ \\
PBB & $4.40 \pm 03$ & $0.36 \pm 04$ & $0.36 \pm 03$ & $0.40 \pm 00$ \\
BBB & $4.20 \pm 02$ & $0.40 \pm 03$ & $0.40 \pm 02$ & $0.42 \pm 01$ \\
\hline
\end{tabular}

Foot note: Mean \pm SD values of five determinations with significantly different $(\mathrm{P}<0.05)$. BD, Basal Dietary; CD, Control Dietary; BPB, Basil I0\% Platelet I0\% Basal 80\% Dietary; PBB, Platelet 10\% Bitter 10\% Basal 80\% Dietary; BBB, Bitter 10\% Basil 10\% Basal 80\% Dietary.

Table 4 The nitrogen retention in various tissues of the internal organ

\begin{tabular}{llllll}
\hline Dietary & Kidneymg/g & Livermg/g & Musclemg/g & Feacal $\mathbf{~ g / g}$ & Urinemg/g \\
\hline BD & $20.20 \pm .00$ & $20.05 \pm 01$ & $10.30 \pm 02$ & $1.20 \pm 03$ & $0.28 \pm 04$ \\
CD & $70.04 \pm 02$ & $70.08 \pm 03$ & $70.06 \pm 03$ & $0.62 \pm 04$ & $0.14 \pm 02$ \\
BPB & $70.64 \pm 01$ & $70.61 \pm 02$ & $70.78 \pm 03$ & $0.80 \pm 03$ & $0.21 \pm 04$ \\
PBB & $50.01 \pm 00$ & $50.02 \pm 04$ & $50.09 \pm 00$ & $0.74 \pm 04$ & $0.14 \pm 04$ \\
BBB & $55.76 \pm 03$ & $55.62 \pm 03$ & $55.69 \pm 03$ & $0.86 \pm 04$ & $0.35 \pm 03$
\end{tabular}

Foot note: Mean \pm SD values of five determinations with significantly different $(\mathrm{P}<0.05)$. BD, Basal Dietary; CD, Control Dietary; BPB, Basil I0\% Platelet I0\% Basal 80\% Dietary; PBB, Platelet 10\% Bitter 10\% Basal 80\% Dietary; BBB, Bitter 10\% Basil 10\% Basal 80\% Dietary.

Table 5 Bioassay of the experimental animal Bioassay

\begin{tabular}{llllllll}
\hline Diet & BV $\%$ & NPU\% & PER & FER & NPR & PRE & Gained/loss \\
\hline BD & - & - & - & - & - & - & -0.62 \\
CD & $71.11 \pm 02$ & $4.11 \pm 02$ & $4.10 \pm 01$ & $6.8 \pm 00$ & $4.05 \pm 02$ & $64 \pm 04$ & $4 I .1$ \\
BPB & $72.06 \pm 01$ & $4.43 \pm 04$ & $4.40 \pm 02$ & $7.3 \pm 03$ & $4.37 \pm 04$ & $69 \pm 02$ & 44.32 \\
PBB & $59.60 \pm 03$ & $1.13 \pm 00$ & $1.10 \pm 03$ & $3.78 \pm 04$ & $1.07 \pm 01$ & $17 \pm 03$ & 11.34 \\
BBB & $63.77 \pm 02$ & $1.33 \pm 02$ & $1.30 \pm 01$ & $4.43 \pm 02$ & $1.26 \pm 02$ & $20 \pm 02$ & 13.30 \\
\hline
\end{tabular}

Foot note: Mean \pm SD values of five determinations with significantly different $(\mathrm{P}<0.05)$. BD, Basal Dietary; CD, Control Dietary; BPB, Basil I0\% Platelet I0\% Basal 80\% Dietary; PBB, Platelet 10\% Bitter 10\% Basal 80\% Dietary; BBB, Bitter 10\% Basil 10\% Basal 80\% Dietary.

\section{Conclusion}

Basil compared with bitter vegetable dietary had the best growth response, both have medicinal value, home based, has health benefits. Nitrogen retention is present in various tissues of the internal organ which is adequate for body physiology and building. Nutrient compositions in the dietary samples meet daily nutrient requirement intake and amino acid profile that is adequate to complement human diet in pregnant women, children and elderly. Protein quality of both basil leaf (ocimum gratissimum) and bitter leaf(vernonia amygdalina) are viable to promote human growth. Basil leaf (ocimum gratissimum) and bitter leaf (vernonia amygdalina) has confirmed to be source of Vitamin-A,C and $\mathrm{K}$ and mineral to support and improve human health of the populace.

\section{Acknowledgements}

None. 


\section{Conflict of interest}

The author declares that there is no conflict of interest.

\section{References}

1. Asaolu SS, Adefemi OS, Oyakilome IG, et al. Proximate and mineral composition of nigerian leafy vegetables. Journal of Food Research. 2012;1(3):214-218.

2. Herbal Plant. 2004.

3. Health benefits of bitter leaf. 2017.

4. Mephba HD, Eboh L, Banigo EB. Effect of processing treatments on the nutritive composition and consumer acceptance of some Nigerian edible leafy vegetables. African Journal of Food Agriculture Nutrition and Development. 2007;7(1):23-26.

5. Brophy JJ, Jogia MK. Essential oils from Fijian Ocimum basilicum L. Flavour and Fragrance Journal. 1986;1(2):53-55.

6. Fagbohun ED, Lawal OU, Ore ME. The Proximate, Mineral and Phytochemical Analysis of the Leaves of Ocimum gratissimum L., Melanthera scandens A. and Leea guineensis L. and their medicinal value. International Journal of Applied Biology and Pharmaceutical Technology. 2012;3(1):105.

7. Baritaux O, Richard H, Touche J, et al. Effects of drying and storage of herbs and spices on the essential oil. Part I. Basil, Ocimum basilicum L. Flavour and Fragrance Journal. 1992;7(5):267-271.

8. Ibironke SI, Ige MM, Adepeju AB, et al. Haematological and Invivo Study of Moringa Oleifera Seed. MOJ Food Process Technol. 2017;4(6):00109.

9. AOAC: Official Methods of Analysis of the Association of Official. Analytical Chemists. 17th ed. Washington DC; 2000. p. 1-771.

10. Ibironke SI, Akinola EA, Adepeju AB. Comparative Study of Condiment Vegetable Basil Leaf (Ocimum gratissimum) and Bitter Leaf (Vernonia Amygdalina). American Journal of Food and Nutrition. 2017;5(3):9598.

11. Aaron SD, Vandemheen KL, Naftel SA, et al. Topical tetracaine prior to arterial puncture: a randomized, placebo-controlled clinical trial. Respir Med. 2003;97(11):1195-1199.

12. Denny P, Hagen FK, Hard M, et al. The proteomes of human parotid and submandibular/sublingual gland salivas collected as the ductal secretions. Journal of Proteome Res. 2008;7(5):1994-2006.

13. Lab Tests Portal. Saliva test to substitute blood test. 2011.

14. MedlinePlus. US: National Library of Medicine. 2016.

15. Kuku A Etti UI, Ibironke SI. Processing of Fluted Pumpkin Seeds, Telfairia Occidentalis (Hook F) as it affects growth performance and nutrient metabolism in rats. African Journal of Food and Agriculture Nutrition and Development. 2014;14(5):1992-2014.

16. Adeniyi MA, Fashakin JB, Ibironke SI. Determination of Mineral Contents, Proximate Composition and Functional Properties of Complementary Diets prepared from Maize, Soybean and Pigeon Pea. American Journal of Nutrition and Food Science. 2014;1(3):53-56.

17. Klimánková Eva, Holadová Kateřina, Hajšlová Jana, et al. Aroma profiles of five basil (Ocimum basilicum L.) Cultivars grown under conventional and organic conditions. Food Chemistry. 2008;107(1):464-472.

18. Freiberger CE, Vanderjagt DJ, Pastuszyn A, et al. Nutrient content of the edible leaves of seven wild plants from Nigerian. Plant foods for human nutrition. 1998;53(1):57-69.
19. Kadiri Oseni, Olawoye Babatunde. Underutilized Indigenous Vegetable (Uiv) In Nigeria: A Rich Source of Nutrient and Antioxidants-A Review. Annals. Food Science and Technology. 2014;16(2):307-318.

20. Jeffrey B Harborne, Herbert Baxter. Chemical Dictionary of Economic Plants J Nat Prod. 2002;65(6):949.

21. Ibironke SI. Formulation of Infant Weaning Foods from Vegetable Proteins and Cereal. American Journal of Food Technology. 2014;9(2):104-110.

22. Ibironke SI, Fashakin JB, Ige MM. Nutritional Quality of Animal Polypeptide (Crayfish) Formulated Into Complementary Foods. American Journal of Food and Nutrition. 2014;2(3):39-42.

23. Ibironke SI, Adeniyi MA, Fashakin JB. Nutritional evaluation of complementary food formulated from fermented maize, pigeon pea and soybeans. Nutrition \& Food Science. 2014;44(5):464-470.

24. Ibironke SI, Fashakin JB, Ige MM. Formulation of Complementary Foods Developed from Plants Polypeptide (Parkia Biglobosa), Soy Bean and Maize. American Journal of Nutrition and Food Science. 2014;1(4):72-77.

25. Ibironke SI, Ige MM. Growth Pattern and Nutritional Status of School Children Aged 6-14 Years of Selected Schools in Osun State, SouthwestNigeria. Annals. Food Science and Technology. 2014;15(2):387-391.

26. Ewuola GO, Ibironke SI, Fashakin JB. Formulation and Nutritional Evaluation of Maize, Bambara Groundnut and Cowpea Seeds Blends Complementary Food. American Journal of Food and Nutrition. 2015;3(4):101-105.

27. Ibironke SI, Ige MM. Nutritional Evaluation and Chemical Analysis of two commercial infant foods in south-western, Nigeria. International Journal of Nutrition and Food Sciences. 2015;4(5):590-593.

28. Ibironke SI, Fawale O. Chemical Analysis and Animal Bioassay of Hildegardia Barteri (Kariya Seed) Soy Bean and Maize. Annals. Food Science and Technology. 2015;16(1):245-250.

29. Ibironke SI, Adepeju AB. Nutritional Assessment of Breakfast Foods Developed From Animal Polypeptide, Crayfish (Euastacus Spp) and Maize (Zea Mays). American Journal of Food and Nutrition. 2016;4(5):131-134.

30. Ibironke SI, Ige MM, Bejide RA. Histopathological and In-Vivo Study of Moringa Oleifera Seed. Annals Food Science and Technology. 2016;17(1):102-108.

31. Drewnowski Adam, Gomez-Carneros Carmen. Bitter taste, phytonutrients, and the consumer: a review. Am J Clin Nutr. 2000;72(6):1424-1435.

32. Ibironke SI, Fashakin JB, Badmus OA. Nutritional Evaluation of Complementary Food Developed from Plant and Animal Protein Sources. Nutrition \& Food Science. 2012;42(2):111-120.

33. Kuku A, Alabi MO, Ibironke SI. Effect of processing on the lectin and trypsin inhibitor content of Plukenetia conophora seeds as it affects growth performance and nutrient metabolism in rat. African Journal of Food Science. 2013;7(9):306-316.

34. Mac Lennan CA, Van Oosterhout JJ, White SA, et al. Finger-prick References blood samples can be used interchangeably with venous samples for CD4 cell counting indicating their potential for use in CD4 rapid tests. AIDS. 2007;21(12):1643-1645.

35. Miele Mariangela, Dondero R, Ciarallo G, et al. Methyleugenol in Ocimum basilicum L. Cv. Genovese Gigante. Journal of Agricultural and Food Chemistry. 2001;49(1):517-521. 
36. Mohammed M I, Sharif N. Mineral composition of some leafy vegetables consumed in Kano, Nigeria. Nigerian Journal of Basic and Applied Science. 2011;19(2):208-211.

37. Oladeji BS, Akanbi CT, Ibironke SI. Physico-Chemical and Nutritional Evaluation of Co-Processed Fermented Yellow Maize Ogi (An Infant Diet) And Carrot Blends. Annals Food Science and Technology. 2014;15(1):82-91.

38. Oladeji BS, Irinkoyenikan OA, Gbadamosi SO, et al. Comparative analysis of physico-chemical properties and amino acids profile of three tropical maize hybrid cultivars in Nigeria. Nutrition \& Food Science. 2016;46(5):695-705.
39. Oloyede FM, Oloyede FA, Obuotor EM, et al. Antioxidant Activities and Food value of Five Underutilized Green Leave Vegetables in South Western Nigeria. The Nigerian Journal of Nutritional Science. 2011;32(1):13-18.

40. Udochukwu U, Omeje FI, Uloma IS, et al. Phytochemical analysis of Vernonia Amygdalina and Ocimum Gratissimum extracts and their antibacterial activity on some Drug Resistant Bacteria. American Journal of Research Communication. 2015;3(5):225-235.

41. Wellness mama. 2018.

42. Joseph Nordqvist. Why everyone should eat basil. IFT. 2018 